The Politics of Researching Multilingually 


\section{RESEARCHING MULTILINGUALLY}

Series Editors: Prue Holmes, Durham University, UK, Richard Fay, University of Manchester, UK and Jane Andrews, University of the West of England, UK

\section{Consulting Editor: Alison Phipps, University of Glasgow, UK}

The increasingly diverse character of many societies means that many researchers may now find themselves engaging with multilingual opportunities and complexities as they design, carry out and disseminate their research. This may be the case regardless of whether or not there is an explicit language and multilingual aspect to their research. This book series proposes to address the methodological, practical, ethical and other options and dilemmas that researchers face as they go about their research. How do they design their research methodology to account for multilingual possibilities and practices? How do they manage such linguistic complexities in the research domain? What are the implications for their research outcomes? Research methods training programmes only rarely address these questions and there is, as yet, only a limited literature available. This series proposes to establish a new track of theoretical, methodological, and ethical researcher praxis that researchers can draw upon in research(er) contexts where multiple languages are at play or might be purposefully used. In particular, the series proposes to offer critical and interpretive perspectives on research practices and endeavours in interand multi-disciplinary contexts and especially where languages, and the people speaking and using them, are under pressure, pain, and tension.

All books in this series are externally peer-reviewed.

Full details of all the books in this series and of all our other publications can be found on http://www.multilingual-matters.com, or by writing to Multilingual Matters, St Nicholas House, 31-34 High Street, Bristol, BS1 2AW, UK. 
RESEARCHING MULTILINGUALLY: 6

The Politics of Researching Multilingually

Edited by

Prue Holmes,

Judith Reynolds

and Sara Ganassin

MULTILINGUAL MATTERS

Bristol • Jackson 
DOI https://doi.org/10.21832/HOLMES0145

Names: Holmes, Prue, editor. | Reynolds, Judith, editor. | Ganassin, Sara, editor.

Title: The Politics of Researching Multilingually/Edited by Prue Holmes, Judith Reynolds and Sara Ganassin.

Description: Bristol; Jackson: Multilingual Matters, 2022. | Series: Researching Multilingually: 6 | Includes bibliographical references and index. | Summary: "This book offers a unique understanding of how researchers' linguistic resources, and the languages they use, are politically and structurally constrained, with implications for the reliability of the research. The book will help readers to make theoretically and methodologically informed choices about the political dimensions of their research"-Provided by publisher.

Identifiers: LCCN 2021049839 (print) | LCCN 2021049840 (ebook) | ISBN 9781800410138 (paperback) | ISBN 9781800410145 (hardback) | ISBN 9781800410152 (pdf) | ISBN 9781800410169 (epub)

Subjects: LCSH: Multilingualism-Research-Methodology. | Multilingualism--Political aspects. | LCGFT: Essays.

Classification: LCC P115 .P577 2022 (print) | LCC P115 (ebook) | DDC 404/.2072—dc23/eng/20211203 LC record available at https://lccn.loc.gov/2021049839

LC ebook record available at https://lccn.loc.gov/2021049840

Library of Congress Cataloging in Publication Data

A catalog record for this book is available from the Library of Congress.

British Library Cataloguing in Publication Data

A catalogue entry for this book is available from the British Library.

ISBN-13: 978-1-80041-014-5 (hbk)

ISBN-13: 978-1-80041-013-8 (pbk)

\section{Multilingual Matters}

UK: St Nicholas House, 31-34 High Street, Bristol, BS1 2AW, UK.

USA: Ingram, Jackson, TN, USA.

Website: www.multilingual-matters.com

Twitter: Multi_Ling_Mat

Facebook: https://www.facebook.com/multilingualmatters

Blog: www.channelviewpublications.wordpress.com

Copyright (C) 2022 Prue Holmes, Judith Reynolds, Sara Ganassin and the authors of individual chapters.

All rights reserved. No part of this work may be reproduced in any form or by any means without permission in writing from the publisher.

The policy of Multilingual Matters/Channel View Publications is to use papers that are natural, renewable and recyclable products, made from wood grown in sustainable forests. In the manufacturing process of our books, and to further support our policy, preference is given to printers that have FSC and PEFC Chain of Custody certification. The FSC and/or PEFC logos will appear on those books where full certification has been granted to the printer concerned.

Typeset by SAN Publishing Services.

Printed and bound in the UK by the CPI Books Group Ltd. 